\title{
Cross-Dressing and the Politics of Dismemberment in Francis Beaumont and John Fletcher's Philaster
}

MARIE H. LOUGHLIN

Summary: Critics often dismiss cross-dressing in Beaumont and Fletcher's Philaster as a meretricious dramatic trick. In reality, cross-dressing becomes a nexus for the play's pervasive anxieties concerning bodily and vestimentary codes, with major characters staking their conflicting claims to political power on their ability to manipulate these codes and the various inner truths which they inscribe. The divestment of the cross-dressed page, Bellario, dramatizes precisely the inability of signifiers to offer certainty concerning the truth within the casing of clothing or the casing of the body.

$\mathrm{F}^{\text {rancis Beaumont and John Fletcher's Philaster is often credited with }}$ establishing a new genre on the Renaissance stage - tragicomedy. While Fletcher's earlier efforts in the genre, The Faithful Shepherdess and Cupid's Revenge, were commercially unsuccessful, in collaboration with Beaumont Philaster was an aesthetic and commercial triumph, with "the record of what was probably an exceptional double performance at Court in the 1612-13 season"1 as well as a long stage history after its initial Renaissance performances. According to Arthur Colby Sprague's study, Beaumont and Fletcher on the Restoration Stage, there are records of Philaster being performed regularly in both London and the provinces between 1660 and 1676; it reappeared in a 1683 "alteration under the title of The Restauration, or Right will Take Place, ascribed to the Duke of Buckingham."2 Samuel Pepys's diary entry for November 18, 1661 offers a back-handed compliment to the play's reputation in Restoration England: "After dinner to Mr. Bow[y]ers at Westminster for my wife, and brought her to the Theatre to see Philaster 
(which I never saw before), but I find it far short of my expectation."3 However, like most of Beaumont and Fletcher's plays, Philaster began to fall out of favour in the late-seventeenth and eighteenth centuries, although both Buckingham's and later Elkanah Settle's adaptations attempted to make the play resonate for changing theatrical tastes and moral standards. Not performed as regularly in the eighteenth century, except in George Coleman the Elder's radical and "exceptionally popular" adaptation, it saw its last London performance in 1796. Modern productions are scant. ${ }^{4}$

Late-seventeenth and eighteenth-century dramatic and aesthetic standards judged Beaumont and Fletcher's plays with increasing harshness because of their alleged moral indelicacy: "Coleman's sole object [in adapting Philaster] was "to remove the objections to the performance of this excellent play." 5 As modern critics, though, we have no reason to feel smugly superior to those who have voiced moral objections to the Fletcher Canon. Indeed, not only has "Philaster lain for most of its life in a critical backwater moved only occasionally by eddies from Shakespeare's romances,"6 but also it has been relegated until recently to the margins of critical discussions of tragicomedy and romance in general. At the same time, attempts to rescue Fletcher from his reputation as a "pornographer . . . talented but irreverent, even flagrantly obscene" have limited the parameters of even this discussion. ${ }^{7}$ Nancy Klein Maguire's anthology Renaissance Tragicomedy: Explorations in Gender and Politics, for all its varied approaches, attempts to recuperate Fletcher's reputation and that of "mungrell Tragycomedie"8 by asserting this genre's essential didacticism and ethical orientation. In short, Maguire and her contributors suggest that tragicomedy aims to teach us a way of seeing and feeling beyond the boundaries of the rational, that tragicomedy is instructively metadramatic. Only recently have critics been able to move beyond the issue of the titillating reputation of Fletcher's works to consider their relationship to various historical, political and cultural contexts. However, Philaster still remains a play which troubles critics, not simply because of the contradictory expectations and reactions which tragicomedy often produces in audiences and readers, but because it seems largely unassimilable to recent critical approaches, particularly those focused on gender, desire and cross-dressing.

Critics as varied as Clifford Leech and Bruce Smith have asserted that cross-dressing in Beaumont and Fletcher's Philaster is (in Smith's words) a kind of "confidence trick" perpetrated on the audience, since of course "the audience is no less deceived by the disguised heroine's gender than the 
characters in the play are." Indeed, cross-dressing in this particular tragicomedy does appear to function in generic terms as a kind of "shopworn theatrical" mechanism which simply serves to bring about the familiar tragicomic turn from imminent tragedy to comic reconciliation and harmony. ${ }^{9}$ As a result, much of the theoretical work on theatrical transvestism which concentrates on this activity's socially and politically transgressive character has seemed largely inapplicable, and thus critics have been particularly reluctant to include Philaster in such discussions. Early feminist criticism, for example, focuses almost exclusively on how Shakespeare's plays use cross-dressing to explore and challenge early modern gender roles. Although some early critics, like Juliet Dusinberre in Shakespeare and the Nature of Women, view dramatic cross-dressing as an empowering practice, which permits female characters to explore and play with gender boundaries, others, like Clara Claiborne Park, see the freedom this practice offers as essentially illusory, given that the cross-dressed woman usually divests herself of her empowering male costume at the play's conclusion, returning to the confines of traditional roles and indeed taking on that most prescriptive of roles - wife. ${ }^{10}$ Regardless of their ultimate attitude towards the liberating potential of cross-dressing, all of these interpretations rely heavily on the audience's special knowledge of the cross-dressed heroine's actual gender, since this model of cross-dressing as allowing an exploration of gender boundaries only works if the audience is aware of the heroine's double status. Philaster lacks this disclosure and thus remains awkwardly outside this critical model.

More recently, critics have absorbed the discussion of cross-dressing within an examination of early modern subjectivity, exploring not only how cross-dressing challenges the binary oppositions of gender, but also how it reveals deep-seated anxieties about the malleable nature of the body, sex and individual subjectivity. ${ }^{11}$ Even with this new model of cross-dressing, however, Philaster still seems a play with which many critics feel uncomfortable. These new readings often suggest that Philaster's depiction of cross-dressing and its exploitation of this practice's erotic pleasures lack the subtlety and sophistication which are typical of this activity's depiction and use in a range of early modern plays. Only recently have critics like Susan Zimmerman, Bruce Smith and Jo E. Miller begun to challenge this view of Fletcher's tragicomedies in general and Philaster in particular. While Zimmerman and Smith are interested in exploring the erotic charge delivered by a mixed generic form like tragicomedy, Miller is more concerned with refuting the 
very assumptions which have often been made about Beaumont and Fletcher's use of the cross-dressed woman in Philaster. For Zimmerman, Fletcher's tragicomedies demonstrate that "the singular pervasiveness of sexual themes in Jacobean drama implicated transvestism to some degree in every dramatic structure, and that in all probability viewer sensitivity to multi-layered eroticism was never wholly suspended." 12 Smith also emphasizes the need to recognize the erotic possibilities opened up by the mixed genre of tragicomedy:

To elide the generic differences between tragedy and comedy is to bring together two very different modes of stimulating homoerotic desire on stage: a mode that defines erotic difference in all-male terms, with a mode that defines that difference in male/female terms; a mode that enacts desire through violence, with a mode that confirms concord; a mode that frustrates desire, with a mode that gives desire satisfaction. ${ }^{13}$

For Smith, the general indeterminacy of tragicomedy and the erotic pleasure it provides does not unfortunately apply to Philaster precisely because of the use of cross-dressing, which exists solely for the playwrights to "sport . . . with a shop-worn theatrical prop."14

While Smith's focus on tragicomedy's mix of generic modes and the erotic possibilities that reside within them is provocative, then, it still cannot address the erotic charge of cross-dressing in Philaster. For Miller, Smith's attitude is part of a longer critical tradition which deplores Beaumont and Fletcher's decision to keep Bellario's true gender a secret until the play's conclusion. There is clearly a radical difference between the critical approaches of Victor Oscar Freeburg's "classic 1915 study of Renaissance disguise plots," Lee Bliss's 1986 exploration of Philaster as tragicomic romance and Bruce Smith's reading of desire in the Renaissance theatre and on the Renaissance stage. ${ }^{15}$ However, Miller's argument also indicates that, like Freeburg and Bliss, Smith sees the secret of Bellario's cross-dressing as a serious obstacle to its incorporation within his critical model. As Miller points out, for Freeburg and Bliss, this secret prevents the audience from experiencing pity for the figure of the love-lorn maid; the revelation of this secret is equally frustrating since it refuses us a tidy romantic conclusion: Bellario/Euphrasia declares her intention never to marry. Thus, according to Miller, cross-dressing in Philaster exposes our desire for the structurally satisfying ending of tragicomedy or romance - marriage - and our desire for the resolution of the pathos which we inevitably feel for Bellario/Euphrasia during her account of her undeclared and hopeless love for Philaster. ${ }^{16}$ Likewise, for Smith, the secret of Bellario's cross-dressing 
prevents the free play of erotic desire on behalf of the characters and the audience, which for him defines the most dangerous, transgressive and satisfying use of the stage device.

An exclusive concentration on the scene of Bellario/Euphrasia's divestment leads naturally to the assumption that the introduction of cross-dressing in Philaster is solely a matter of generic codes and dramaturgical convenience. Placing this moment of revelation within the play's larger political and epistemological concerns suggests that cross-dressing is far from simply a dramatist's trick, which effectively defuses a socially and politically threatening practice by subsuming it within the conventional exigencies of the tragicomic genre. To say that Philaster even has larger political and epistemological concerns is to adopt what is, in the tradition of Fletcher criticism, a minority view. As Philip Finkelpearl has noted, "the political aspect of Philaster is rarely considered important enough to mention," with critics from Eugene Waith to Andrew Gurr either ignoring or dismissing even its most obvious connection to contemporary political issues - its criticism of monarchical absolutism. Like Gordon McMullan's and Philip Finkelpearl's work, however, this paper asserts that Philaster is deeply concerned with contemporary political and social issues, particularly with the precedent James's own political treatises offered for representing the political in sexualized and familial terms. ${ }^{17}$ Arguably, in Philaster, crossdressing encodes issues of inheritance and monarchical legitimacy in sexual and vestimentary terms. In fact, only in this context, in terms of the anxiety produced by bodily and vestimentary codes throughout the drama, can we truly understand the significance of cross-dressing at the conclusion of the play as well as its crucial role in asserting Arethusa's chastity and stabilizing the state. Since both the king and Philaster himself stake their conflicting claims to political power and authority upon their ability to control and define the terms within which such codes signify, there is a great deal of emphasis placed on the political and epistemological stability of the relationship between bodily as well as vestimentary signifiers and the various inner or hidden truths to which they refer. However, the violent production of this stability in the actual wounding of Arethusa and Bellario as well as in the threatened torture of the effeminate Spanish prince, Pharamond, reveals a terrible consciousness of precisely the inability of signifiers to offer certainty concerning the truth within the casing of clothing or the casing of the body.

Given the lack of widespread critical interest in the play, a short summary of the plot seems in order. At the beginning of the play, we are 
introduced to the King of Calabria who is attempting to legitimate his usurpation of the throne of Sicily by arranging a marriage between his only child, Arethusa, and the Spanish prince, Pharamond. Amidst the muttering dissension of the Sicilian nobles, the true heir to the throne, Philaster, appears to assert his claim, although much more tentatively than nobles such as Dion desire. Arethusa is in love with Philaster and he with her, which explains his hesitancy; when Arethusa reveals her love to Philaster, he decides to give her his page, Bellario, a young man extremely devoted to him, "to wait on [her], and bear [their] hidden love" (1.2.140). Unfortunately, soon after this decision, the king discovers the intemperate prince, Pharamond, in sexual dalliance with the corrupt court lady, Megra. To save her own reputation and to silence the king's threats to advertise her licentiousness, Megra accuses Arethusa of sexual involvement with Bellario. Dion subsequently takes advantage of this slander to kill Philaster's love for Arethusa and thus persuade him to seize his usurped throne; he lies to Philaster, saying that he himself found the two in bed together. Philaster falls into a rage, interrogates both Bellario and Arethusa, dismisses all their protestations of virtue and decides to retreat to a rough pastoral existence. Coming upon Arethusa and Bellario separately in the woods, where Arethusa has gone to participate in a royal hunt and Bellario to lament his rejection by his master. Philaster wounds first Arethusa. A Country Fellow, however, stops the assault and in turn wounds Philaster. Stumbling through the wood, Philaster comes upon a sleeping Bellario, wounds him and falls to the ground. Although Bellario tries to take the blame for Arethusa's wounding, Philaster proclaims his own guilt; he and Bellario are condemned to death. However, before the sentence can be carried out, there is a popular uprising against the King of Calabria and Pharamond, during which Pharamond is abused and humiliated by a mob which only Philaster can quiet. He does so and in gratitude, the king gives Arethusa to Philaster along with the throne of Sicily. However, Megra turns up at the end of the play to repeat her accusations against Arethusa and Bellario. Arethusa is incapable of proving her innocence and seems in imminent danger of being disowned when Bellario reveals that she is really a woman, Euphrasia, daughter of Dion; she has long been in love with Philaster and decided upon this disguise in order to serve him, since she had no hope that she would ever be his wife. The play concludes with Bellario/Euphrasia refusing the king's offer of a noble husband and asking instead to serve both Arethusa and Philaster in their new household. 
The play's political anxieties surround the King of Calabria's attempts to assert the legitimacy of his claim to the usurped throne of Philaster. By betrothing his daughter, Arethusa, to the Spanish prince, Pharamond, the king aims at establishing his ownership of usurped Sicily through that which he can be unquestionably said to own: his daughter's virginal body. Obviously, by contracting this match he asserts his legitimate right to Sicily through his disposal of it, through his gaining of an "heir" in Pharamond. Clearly, then, the king's ability to stabilize the fractured political landscape of Sicily and legitimize his monarchical claims depends on Arethusa's status as chaste and virginal commodity. The king's lengthy public declaration of his daughter's virginity is, as a result, perfectly unremarkable; it would appear that there is nothing more certain in this scene than Arethusa's virginity. Apart from her cloistered life, her lack of knowledge about desire and her fearful blushes, the king also relates more explicitly to her body's physical testimony to her virginal state, when he refers to her possession of "these undivided parts, / That must mould up a virgin" (1.1.98-99). However, his use of external signs to affirm Arethusa's virginity, his attempt to transform her body into that which speaks for itself, occurs in an extremely problematic context: the king couches his entire description of his daughter's virginity in terms which underline the uncertainty surrounding the very signs he is offering as proof of this state. He begs Pharamond, for example, to cast away any doubt that Arethusa's demeanour and bodily signs may constitute "borrowed ornaments" which "add / An artificial shadow to her nature" (1.1.100, 101-102). Moreover, in the same breath that he "boldly dare[s] proclaim her yet / No woman," he introduces the image of "a Queen, whose eye / Speaks common loves and comforts to her servants" (1.1.103-104, 106-107). The king ostensibly introduces the hypothetical, licentious queen as a contrast to Arethusa. The effect of the passage is, of course, to stress the unreliability of those bodily signifiers which purport to demonstrate a woman's virginal state. Virginity is a state which traditionally in the period refers to the interior of the female body, to that membrane which becomes a site of pure ambiguity in early modern discourse - the hymen itself. ${ }^{18}$

It is the need to arrest the play of virginal signifiers, to efface the radical indeterminacy and contingency of the marks of virginity, which triggers the play's extensive series of sexualized physical assaults. The epistemological model which the king instantiates, a model of outer signifiers gesturing firmly and unmistakably towards inner truth, is one which implies the necessity of exposing what lies hidden. When it is the body which is the 
epistemological object in question, obviously violence, torture and dismemberment become methods for uncovering the truth beneath, for ascertaining the relationship between surface and depth. ${ }^{19}$ The victims' attitudes towards the violence with which they are threatened indicate that the discourses of violence and dismemberment are not simply products of Philaster's personal grief and rage but of the whole society's deep investment in and anxiety about the stability of bodily and vestimentary signs. When Arethusa finds that she is suspected of unchastity, she protests her innocence by demanding: "Make my breast / Transparent as pure crystal, that the world, / Jealous of me, may see the foulest thought / My heart holds" (3.2.144-147). When she realizes that the bodily mediation of her inner truth cannot be dispensed with, she desires to be ripped to pieces and her "story written in [her] wounds" (3.2.187); Arethusa's desire for a transparent body translates into a desire for a dismembered one, since in the process of dismemberment the body's interior is opened to the gaze and the necessary relationship between surface signifier and inner signified is supposedly demonstrated.

Philaster's demand that Bellario reveal his innermost thoughts is also connected with the belief that the revelation of inner truth is a function of bodily disintegration. "Tell me thy thoughts," Philaster says to Bellario, "for I will know the least / That dwells within thee, or I will rip thy heart / To know it; I will see thy thoughts as plain/ As I do now thy face" (3.1.235-238). Bellario's reply echoes Arethusa's belief in this model of truth, since he imagines his dismembered body as a thing which will testify to his inner fidelity: "Hew me asunder, and whilst I can think / I'll love those pieces you have cut away / Better than those that grow, and kiss those limbs / Because you made 'em so" (3.1.255-258). Although neither Bellario nor Arethusa are indeed dismembered in the course of the play, their wounding and the blood which accompanies it bring to the surface a sign which testifies to their fidelity and truth.

At the same time, the play's depiction of Arethusa as a willing participant in the discourse of dismemberment and the practices of violence indicates how this model of truth is heavily gender-inflected. Arethusa could not put more plainly her desire to die at Philaster's hands: "If my fortune be so good to let me fall / Upon thy hand, I shall have peace in death (4.5.65-66). Moreover, when the Country Fellow happens upon the scene just after Philaster has wounded Arethusa, her response to his assistance both underscores her willing participation in an erotics of domination, in the production of the bloody signs of her subordination to Philaster, and as a result the 
specifically gender-inflected nature of the testing of such external signs' validity. Refusing to see her wounding as anything but one among a number of innocuous aristocratic pleasures, "private sports" or "recreations" (4.5.91), Arethusa contributes to a definition of the relationship between bodily signifier and internal truth which simultaneously produces female subordination.

Bellario's explicit feminization in his role as young and helpless page also demonstrates how the gender-inflected nature of the play's discourses of dismemberment and violence as well as the truth which they seek to produce go beyond the virginal body to encompass all the play's feminized (and indeed effeminate) bodies. As Lisa Jardine has suggested in her discussion of the Renaissance hermaphrodite, such a figure is not one "incorporating both sets of sexual parts ... but the erotically irresistible effeminate boy," whose most sexually compelling characteristics are specifically effeminate: "submissiveness, coyness, dependence, passivity, exquisite whiteness and beauty." ${ }^{20}$ In these terms, Philaster's description of Bellario as a "tender youth" who "bear[s] a childish overflowing love / To them that clap [his] cheeks and speak [him] fair. .." and who is a "gentle boy" given to weeping $(2.1 .2,16-17,49)$ is highly erotic, emphasizing Bellario's effeminate subordination to his master. In the play, the urgently needed stability of bodily and vestimentary codes becomes closely connected with the stability and legibility of conventional gender relations: Philaster, in his role as Arethusa's husband-to-be and Bellario's master, thoroughly subordinates both the princess and the young page.

Philaster's certainty concerning the fidelity of Bellario and the virginity of Arethusa occurs directly after he has wounded Bellario, who views this stabbing as a blessing. In fact, Bellario's blood serves the purpose of intensifying his loyalty and emphasizing his determination to help Philaster escape the search party of the king: "These little wounds I have / Ha' not bled much; reach me that noble hand" (4.6.38-39). Philaster in turn finally testifies to both Bellario's and Arethusa's innocence, and incidentally to the methods by which his certainty has been achieved, by refusing to allow Bellario to take the blame for Arethusa's wounding. The violent interrogation of these two subordinate bodies leads to the recuperation of external signifiers of inner purity, as Philaster's description of Bellario's blood mystifies an important somatic sign, transforming it into a potent symbol of truth:

'Tis not the wealth of Plutus nor the gold Locked in the heart of earth can buy away 
This armful from me, this had been a ransom To have redeemed the great Augustus Caesar, Had he been taken. You hard-hearted men, More stony than these mountains, can you see Such clear pure blood drop and not cut your flesh To stop his life, to bind whose bitter wounds Queens ought to tear their hair, and with their tears Bathe 'em? Forgive me, thou that art the wealth Of poor Philaster (4.6.122-132).

Clearly, Philaster figures Bellario's exemplary service, the love between boy and lord which "would outdo story," as evidence of his page's innocence (2.1.60). Bellario's blood thus becomes a sign of perfect service, of absolute subordination to the interests of a beloved master, a service which bests even the period's numerous idealized tales of pages and their loyalty in romances like The Faerie Queene. The reification of the page's blood as more valuable than the mythic hoard of Plutus or the equally fabled gold at the centre of the world clearly reinforces the idealized representation of Bellario's fidelity.

Equally, by imagining Bellario and his blood as capable of ransoming the great Caesar Augustus, Philaster emphasizes their worth. This image, however, also suggests once again Bellario's valuation in terms of abjection, subordination and self-sacrifice. Philaster is, of course, implicitly comparing this imaginary ransoming of the great Roman general and empire-builder to his own attempted ransoming by Bellario, when the page tries to take the blame for his master's stabbing of the princess Arethusa. More importantly, the flow of Bellario's "clear pure blood" forms the most compelling and public evidence of the page's fidelity, and by implication, in this world where the line between discourses of physical and sexual penetration begins to blur, of Arethusa's virginity. Blood becomes that signifier which has a "pure" and "clear" relationship to an individual's inner signified, to Bellario's truth and Arethusa's unbroken hymen.

While Finkelpearl presents Philaster's acceptance of the flimsy accusations brought against Arethusa and Bellario as "a natural extension of the weak, erratic figure of the first two acts," a figure "as languid and worldweary as Tennyson's Mariana" and as peculiarly "passive [and] willless," there is clearly more going on here than can be accounted for by either Finkelpearl's character analysis or by Eugene Waith's more fully developed theory that in Fletcher's plays consistent characterization bows to the exigencies of tragicomedy. ${ }^{21}$ No sooner do the play's external signifiers of inner truth achieve both legibility and stability through their violent, gender- 
inflected production than this certainty begins to crumble. While the discourse of dismemberment aims at revealing and indeed producing the feminized body as naturally subordinate, at the same time the play's politically-fractured landscape means that this discourse comes to affect Philaster himself as much as the female and feminized characters. In recognizing that Philaster himself is caught up in relations which define him as a subordinate, as an individual who in this case is subject to the power of an illegitimate monarch, we also recognize that Philaster's body verges on becoming the same kind of feminized subordinate body over which he has so recently established his control.

As a result, the prison scene where Philaster reconciles with Arethusa and Bellario, a scene where ostensibly he demonstrates how violence has stabilized and defined quite successfully the gender-inflected relationship between outer signifier and inner truth, is actually haunted by the same uncertainty which has driven the violent interrogations in the first place When Philaster imagines his own threatened torture and dismemberment at the hands of an incensed mob, a mob which he believes will tear him to pieces for doubting the fidelity of the two people who love him most, the wording emphasizes his own continued doubts concerning whether they really are the faithful woman and loyal page which they appear to be: "People will tear me when they find you true / To such a wretch as I; I shall die loathed ... Every just servant, every maid in love, / Will have a piece of me, if you be true" (5.2.25-27, 30-31). This slippage from "when they find you true" to "if you be true" indicates the fragility of the certainty Philaster and his society have achieved, as well as the inefficacy of the violent production and legitimation of the play's dominant epistemological model. His reintroduction of the doubt which he has banished only a scene earlier also shows how Philaster's double position as powerful patriarch and powerless king introduces intolerable contradictions. Philaster's doubt implies the necessity to return to the violence which at least temporarily empowers and stabilizes the outerinner epistemological model; his doubt, however, also implies the general failure of violence and the discourse of dismemberment to produce a stable version of this model.

The substitution of Pharamond for Philaster partially defuses Philaster's subordinate position and his imminent effeminization. Near the end of the play, the loyal citizens of Sicily harass and threaten Pharamond with a variety of symbolically - and politically - significant tortures. While Ian Fletcher has depicted the mob of workmen as "good-humouredly ferocious towards 
Pharamond," "easily persuaded to disperse by Philaster," and "manipulated by the aristocrats for their own ends," other critics have seen them as much more than simply "a political deus ex machina" and yet another example of the way Fletcher constantly pulls his dramatic bacon out of the fire through "frankly artful means." 22 As Peter Davison and M. G. M. Adkins have suggested, the citizenry's intervention is a powerfully disruptive action, implying the reliance of the monarch's power on the common people and the fragility of his position in the face of their disquiet. ${ }^{23}$ In the context of my argument, however, the citizen mob's actions and threats are significant particularly in the way they differentiate Philaster from Pharamond. The citizenry's threat to torture Pharamond to death by carving into his body the elaborate designs which decorate his clothing allows the displacement of Philaster's effeminacy and subordination onto the familiar stock figure of the licentious Spaniard; male effeminacy, in other words, becomes the province of the foreigner alone. This torture also marks Pharamond (not to mention the citizens themselves) as a barbaric other, which Philaster must discipline and control. It is provocative that Robert Gaynsh chooses similar metaphors to describe Guinean ritualistic self-engraving, where "the princes and noble men use to pounce and rase their skinnes with pretie knots in divers formes, as it were branched damaske, thinking that to be a decent ornament." 23 At the same time, Pharamond's threatened torture also occurs in terms which point to the instability between signifier and signified that has plagued the whole action.

While sometimes dismissed as part of Beaumont and Fletcher's general contempt for the working and trade classes, the mob's threatened dismemberment of Pharamond is clearly connected with his overly elaborate and therefore effeminate dress. ${ }^{24}$ The captain of the citizens describes him contemptuously as "my pretty Prince of puppets" (5.4.23), a "trim [i.e. prettily dressed] man" (5.4.29), and a "slight Prince of single sarcenet . . . fit [only] to have . . . every boy beat [him]" (49, 50-51). His effeminacy in dress calls forth the threat of an appropriate torture, one which is imagined as cutting his skin into the designs found on a piece of expensive cloth: "branch me his skin / in flowers like a satin, and between every flower a mortal / cut; your royalty shall ravel" $(5.4 .38-40)$. The captain even wishes for a whip so that he can produce effects like the elaborate lace edgings of Pharamond's clothes. At the same time, the significance of Pharamond's threatened torture goes beyond the simple fact that the tradesmen want to punish appropriately his effeminacy and his participation in Philaster's 
usurpation by inscribing his hateful effeminate attire directly onto his body. Through metaphors of engraving, the play expresses a powerful longing for the erasure of distinctions between vestimentary signifiers and the body beneath. Indeed, this scene asserts the legibility and stability of vestimentary codes by presenting clothing as an inseparable part of the body itself. In this way, the threatened torture is an attempt to eradicate the uncertainty which keeps coming back to haunt the play concerning the stability of the relationship between social signifiers in general and their signifieds.

Obviously, some serious contradictions in Philaster's scene of the threatened bodily engraving quickly become evident. The metaphor apparently cannot contain the play's anxieties concerning the very relationship between clothing and the body beneath. In many ways, by making Pharamond's clothes an integral part of his body, the mob indulges in an epistemological fantasy of inseparability of signifier and signified, a kind of hyper-materialization of vestimentary signifiers. This fantasy speaks to the continued suspicion that signifiers have no necessary or stable relation with their signifieds, that clothing conceals rather than reveals what lies beneath. In fact, the engraving of Pharamond's clothing upon his body simply creates another surface requiring interpretation. As a result, the imagined torture gives way to images of total dismemberment and indeed of disembowelling. Thus the discourse of dismemberment succeeds that of engraving as the next step in Pharamond's imagined torture, as uncertainty concerning the legibility of such merged bodily/vestimentary signs is succeeded by a return to that outer/inner model of truth which this fantasy cannot eradicate. Although the Captain forbids his men to castrate Pharamond (since according to his reasoning Pharamond is already emasculated), the citizens begin claiming other parts of his body, his "arm[s]," "leg[s]," "nose," "guts," "liver" and "skin" for various useful purposes. The discourse of dismemberment clearly helps to contrast Pharamond's "womanish" cowardice and effeminate body with Philaster's manly nobility of soul, since Philaster's rescue of the foreign prince from the mob serves as an opportunity for our hero to exercise the power which accompanies his newly-regained position as king of Sicily. The images of dismemberment also imply a return to an anxiety-ridden and largely unsuccessful means of producing bodily certainty, to an assertion that delving beneath the body's surface is necessary in order to discover the relationship between surface and depth. In short, the return to images of dismemberment demonstrates the anxiety over the separability of clothing from what it should signify. 
The play's conclusion and its apparently abrupt introduction of crossdressing, ostensibly to resolve the final difficulties concerning Arethusa's chastity, suggest the over-determined nature of the play's political and epistemological projects. Certainly, the appearance of the cross-dresser, that figure which most thoroughly problematizes the relationship between vestimentary signifiers and the body beneath, cannot by this point simply be dismissed as dramatic sleight-of-hand. The play is approaching its requisite happy ending, with Philaster restored to the throne, the Lady Arethusa promised to him as his wife and the revolution of the common people quelled, when the charges of unchastity which have been made earlier against Arethusa and Bellario resurface. Having been given Arethusa by the king, Philaster proceeds to exercise his newly authorized power by humiliating Pharamond; he offers his former rival the licentious court lady, Megra, crudely asking the Spanish prince whether he likes "this piece" (5.5.25). Just as she earlier attempted to taint Arethusa's chastity and thus deflect attention from her own less-than-spotless reputation, so Megra once again accuses Arethusa of unchastity with Bellario: "Others took me and I took her and him" (5.5.36).

The repetition of the play's action in miniature demonstrates a compulsive reiteration of issues surrounding bodily and vestimentary codes. Any certainty concerning the innocence of these two individuals collapses, as the king rescinds his belief that Arethusa is Philaster's by "right," and thus implicitly the chaste commodity if 1.1: "Clear thou thyself, or know not me for father" (5.5.40). Arethusa's cry, "This earth/ How false it is! What means is left for me / To clear myself? It lies in your belief," and her subsequent and desperate request that such faith serve as the basis for truth are rejected as firmly as they are earlier in the play (5.5.41-43). Instead of heeding Arethusa's request, "My lords, believe me and let all things else / Struggle together to dishonour me," the king seizes on the tortured opening of the body as a means of testing the ephemeral state of sexual innocence. When the king orders Bellario's torture, he embeds once again the demonstration of Arethusa's virginity and Bellario's honesty within the epistemological model which has proven so faulty throughout: "Bear away that boy / To torture. I will have her cleared or buried" (5.5.65-66). Moreover, in extracting a promise from Philaster prior to the order for Bellario's torture that he will not interfere, the king produces the circumstances wherein the threat of self-mutilation becomes the only means of demonstrating inner truth. Philaster tries to stab himself out of remorse for his unwitting part in 
Bellario's sentencing: "Is it in the power / Of flesh and blood to carry this, and live? (5.5.79-80).

The last scene's reuse of the play's dominant epistemological model does not, however, resolve its problems. In fact, the second of Philaster's suicide attempts speaks directly to the continued uncertainty which haunts the external signs of the body in general and the chaste female body in particular. Bellario/Euphrasia, recognizing that only her divestment can save her from torture, takes her father, Dion, to one side and reveals privately to him her true identity. When Dion realizes that his daughter has been crossdressed throughout, he declares in horrified embarrassment: "All's discovered" (5.5.130). In reply to this ambiguous statement, Philaster turns to the men who are preventing him from killing himself and says: "Why then hold you me? / All is discovered. Pray you let me go" (5.5.130-131); he then tries to stab himself again. It is the second attempt which leaves us wondering what Philaster has interpreted this vague "all" to mean. As in the prison, we suspect that Philaster still has doubts about Arethusa's virginity and Bellario's truth.

Ironically, it is only the revelation of the gender inappropriateness of Bellario's clothing to the body which lies beneath that constitutes the absolute proof that Arethusa is still a virgin, since Bellario/Euphrasia lacks the male organ necessary to have accomplished the princess' defloration. Philaster's comically emotional outburst at this revelation and his repetition of the phrase "It is a woman!" emphasize his relief that Arethusa has been proved "fair / And virtuous still to ages in despite of malice" (5.5.140-141), but also set up an ironic juxtaposition between this scene and that of Pharamond's threatened bodily engraving. There, the connection between vestimentary as well as bodily signifiers and their inner signifieds is revealed as a failed fantasy of stability and legibility; here, the belief in Arethusa's chastity and the subsequent political stability which depends on this sexual innocence rely precisely on being able to recognize the gender-inappropriate nature of Bellario/Euphrasia's clothing. The obvious implication is two-fold and self-cancelling: first, to recognize that Bellario/Euphrasia's male clothing belies rather than testifies to the nature of the body beneath indicates this society's ability to read accurately the social signs of gender, sex and sexuality; second, the recognition of this discrepancy expresses the malleable and counterfeit nature of these very signs. Moreover, the necessity for Bellario to be a cross-dressed girl in order for Arethusa to be cleared of charges of unchastity implies not only the failure of this society's project of 
stabilizing the relationship between bodily/vestimentary signifiers and their signifieds, but also this epistemological model's status as a necessary social fiction. That is, by obessively reintroducing the play's inner-outer epistemological model and its violent treatment of the body, Beaumont and Fletcher demonstrate their crucial importance. Even though this model and its concomitant violence are compulsively attractive, the attempts to produce the virginal and feminized body as a compendium of reliable signifiers come to nothing. Clearly, Bellario/Euphrasia's cross-dressed body becomes the pointedly ironic and over-determined grounds for the virginal body's verification.

Bellario/Euphrasia's cross-dressed body, then, far from constituting a dramatist's trick which will help establish political and social stability, actually leads to a series of irregular relationships which reveals the playwrights' expansion of the stock figure of the cross-dressed page; that is, Bellario/Euphrasia does not function, in the words of Lee Bliss, only as a kind of deus ex machina to bring about the familiar tragicomic turn towards harmony and reconciliation. Indeed, her narrative of desire and her refusal to move from the role of virgin to chaste wife signal Beaumont and Fletcher's exploitation of the erotic ambiguities provided by the merging of tragedy and comedy, ambiguities which Bruce Smith has discussed at some length. However, Bellario/Euphrasia's refusal to marry and her account of her chaste love for Philaster never offer anything as complete as an "alternative articulation of feminine selfhood." 25 Even Bellario/Euphrasia's adventurous choices and perpetually virginal body are drawn within some very conventional romance and medical narratives of female desire. For example, her account of falling in love with Philaster when the young prince arrives for a visit with her father emphasizes both the platonic and sensual nature of her love, placing her desires firmly within the discourses of romance literature and early modern physiology. She describes her early desire to see Philaster, based on her father's praise of him and her first view of the young prince, in a psychological and physical sequence taken from the idealizing discourses of romantic love and the symptomology of erotic desire:

My father oft would speak

Your worth and virtue, as I did grow

More and more apprehensive I did thirst

To see a man so raised. But yet all this

Was but a maiden-longing, to be lost

As soon as found; till sitting in my window,

Printing my thoughts in lawn, I saw a god, 
I thought (but it was you), enter our gates. My blood flew out and back again as fast As I had puffed it forth and sucked it in Like breath; then was I called away in haste To entertain you. Never was a man, Heaved from a sheep-cote to a sceptre, raised

So high in thoughts as I; you left a kiss Upon these lips then which I mean to keep From you for ever; I did hear you talk Far above singing (5.5.158-174).

The blushes, the paleness, the exaltation of the beloved and the "maiden-longing" all emphasize Bellario/Euphrasia's psychosomatic reactions to Philaster's presence. ${ }^{26}$ They are all part of the conventional description of female erotic desire in romances such as The Faerie Queene, where (for example) Britomart looks into a mirror, sees Artegall, falls immediately in love and experiences the deleterious physical, emotional and psychological effects of this condition (III,ii, v. 22-47). However, these reactions also suggest the symptoms of erotic melancholy, a suggestion which is compounded by the oblique reference to that disease of hyper-sexuality - chlorosis, greensickness or "maiden-longing" — which is part of the construction of heterosexual virginal desire in early modern Europe. Chlorosis, or greensickness, is of course that hysterical disease which was believed to afflict only virgins. It was triggered by unsatisfied sexual desire and the subsequent retention and corruption of female seed (which many medical manuals stated could only be expelled during female orgasm); it also had many symptoms, among them those noted in Bellario/Euphrasia's narrative as well as those which would sit uneasily in her account of chaste desire and which are thus erased: unnatural cravings, the loss of female modesty and the frantic as well as indiscriminate search for a sexual partner. While there were a variety of suggested cures, including various pharmacological remedies, certain pessaries and specialized areas to be targeted for venesection, marriage, lawful intercourse and the ejaculation of woman's corrupted seed remained popular prescriptions throughout the period. 27

Bellario/Euphrasia's parenthetical recognition that Philaster is not a "god" and her definition of her love as distinct from "lust" suggest that she is hardly sunk in that obsessive concentration on the image of the beloved which defines the true erotic melancholiac. Even so, the playwrights' introduction of oblique references to the disease of lovesickness and the 
symptomology of female sexual desire indicates that they are interested in not just the narratives of idealized desire which are typical of chaste women in Renaissance romance, but also the narratives of pathological desire which are typical of medical discourses treating the diseases of women. Thus, Beaumont and Fletcher combine the beginning of a common romance narrative of desire, in which a chaste woman adopts male disguise and sets off in pursuit of her beloved, and an equally common medical narrative of desire, in which the young virginal woman, her sexual desires awakened at puberty, is prescribed marriage and the attendant emotional and physiological release of lawful intercourse as a wise preventative measure against a variety of hysterical diseases - chlorosis among them. ${ }^{28}$

In this carefully constructed narrative, then, Beaumont and Fletcher present a conventional beginning to Bellario/Euphrasia's female autobiography of desire, the telos of which (both in romance and medical narratives) leads to the same place: marriage. However, the playwrights have slyly set up Bellario/Euphrasia's story in terms of these well-known narratives precisely in order to disrupt their socially and culturally conventional outcomes, since our heroine flatly refuses to conform herself, her body or her desires to them. She decides, finally, to remain a perpetual virgin, a decision which, while couched in the language of religion and vow, creates a disturbing moment within the play's harmonious conclusion and within Bellario/Euphrasia's narrative. The king, presumably impressed by her fidelity, but probably also relieved that his daughter has been so unambiguously cleared of sexual licentiousness, commands the young ex-page: "Search out a match / Within our kingdom, where and when thou wilt, / And I will pay thy dowry; and thyself / Wilt well deserve him" (5.5.191-194). However, this attempt to fulfil the telos of Bellario/Euphrasia's narratives of desire by moving her into a world where marriage and lawful heterosexual initiation construct the body and role of woman is patently unsuccessful. Bellario/Euphrasia refuses this offer to normalize her body and her desires by invoking the sanctity of her religious vow: "Never, sir, will I / Marry; it is a thing within my vow" (5.5.194-195). Her final request is to remain with Philaster and Arethusa, in what one critic has called "an oddly platonized ménage à trois": "But if I may have leave to serve the Princess, / To see the virtues of her lord and her, / I shall have hope to live" (5.5.196-198). ${ }^{29}$ Bellario/Euphrasia's desire is once again placed within the idealizing discourse of the romance and the definition of the erotic melancholiac, who predicates his/her existence on the continued sight of the beloved. Moreover, 
her creation of a new object of desire, in the form of Philaster and Arethusa as a couple, suggests how thoroughly disruptive is Bellario/Euphrasia's rejection of marriage.

This reiteration of two of the most important elements of her earlier narrative of desire is also a reiteration of how Bellario/Euphrasia's crossdressing and its results continue to disrupt the sexual and political world of the play. This unease cannot be dismissed as simply a result of a twentiethcentury critic's sensitivity to issues of gender, since Philaster's two radically different quarto versions suggest that the play's ending has always provoked discomfort. While the provenance of these two quarto versions is still very much in dispute, with the "bad" Q1 published in 1620, two years before the "good" Q2, the conclusion of Q1 is provocative. In this version, Bellario/Euphrasia and Galatea are wed to two minor courtier characters, Cleremont and Thrasiline, respectively. It may be true, as James E. Savage contends, that these changes are aimed at making Bellario/Euphrasia seem less like Arabella Stuart, whose distant claim to the throne led James to forbid her permission to marry. If so, this contemporary connection simply reinforces the more general unease with the play's violation of generic expectations and social norms in Bellario/Euphrasia's refusal to marry. ${ }^{30}$

Bellario/Euphrasia's decision to remain a perpetual virgin, to (in Philaster's words) "be laid in earth / Without an heir" (5.5.204-205), emphasizes the dangerous liminality of her body. She rejects the roles of wife and mother, and this incorporation within the normative structures of patrilinearity, inheritance and patriarchal marriage. ${ }^{31}$ The stabilization of Arethusa's virginal body through its imminent dissolution in the marriage bed is undercut by Bellario/Euphrasia's refusal to duplicate this pattern. Her decision to maintain her virginity creates a sexually and psychologically fraught triangle, partly implied through Arethusa's statement that she will never be jealous of Bellario/Euphrasia's presence. Moreover, her intention to remain aloof from the "fulfilled" sexuality of marriage also reminds the reader of the homoerotic possibilities simultaneously suggested and effaced in the revelation of Bellario/Euphrasia's true gender. The assumption that this revelation obviates the possibility of a sexual relationship between the play's two major female characters. While on one level the divestment of Bellario/Euphrasia seems to resolve the play's social, political and gender anxieties, on another, it declares the instability of the apparent bodily and sexual truths which lie beneath the doublet and hose. Instead of constituting the willing subordination of the self to a male hegemony, the disguised 
woman's divestment in Philaster ironizes this comic convention. Although Bellario/Euphrasia's choice of perpetual virginity may, on the one hand, be seen as a male fantasy of woman's complete subordination and service, on the other, it is also a choice which emphasizes the constant, imminent instability of any political state which relies metaphorically and actually upon the demonstrable nature of woman's sexual innocence.

Okanagan University College

\section{Notes}

1. Andrew Gurr, Introduction of Philaster, or Love Lies a-Bleeding, by Francis Beaumont and John Fletcher, ed. Andrew Gurr (London: Methuen, 1969), p. 1xxi. All subsequent references to the play are to this edition. Gurr qualifies this assertion; while some critics believe that the play was indeed performed twice that year, others believe that a single performance was simply recorded twice.

2. Beaumont and Fletcher on the Restoration Stage (New York: Benjamin Blom, 1965), p. 64.

3. The Diary of Samuel Pepys, vol. II, 1661, ed. R. C. Latham and W. Matthews (London: Harper Collins, 1995), pp. 215-216. He is much more complimentary of a later performance, May 30, 1668.

4. Gurr, p. Ixxiii.

5. Ibid., p. lix.

6. Nancy Cotton Pearse, John Fletcher's Chastity Plays: Mirrors of Modesty (Lewisburg, PA: Bucknell University Press, 1973), p. 17.

7. Sir Philip Sidney, An Apologie for Poetrie in Elizabethan Critical Essays, ed. G. Gregory Smith, 2 vols. (1904; rpt. London: Oxford University Press, 1937), vol. 1, p. 199.

8. "Making a Difference: Male/male 'Desire' in Tragedy, Comedy and Tragicomedy," in Erotic Politics: Desire on the Renaissance Stage, ed. Susan Zimmerman (London: Routledge, 1994), pp. 142-143. For similar views, see Eugene Waith, The Pattern of Tragicomedy in Beaumont and Fletcher (New Haven: Yale University Press, 1952), p. 18; and Philip J. Finkelpearl, Court and Country Politics in the Plays of Beaumont and Fletcher (Princeton: Princeton University Press, 1990), p. 162.

9. Juliet Dusinberre, Shakespeare and the Nature of Women (New York: Macmillan, 1975); and Clara Claiborne Park, "As We Like It: How a Girl Can Be Smart and Still Popular" in The Woman's Part, eds. Carolyn Ruth Swift Lenz et al. (Urbana: University of Illinois Press, 1980), 100-116.

10. See Laura Levine, Men in Women's Clothing: Anti-Theatricality and Effeminization, 1579-1642 (Cambridge: Cambridge University Press, 1994), 1-25; and Catherine Belsey, "Disrupting Sexual Difference: Meaning and Gender in the Comedies," in Alternative Shakespeares, ed. John Drakakis (London: Methuen, 1985), 166-190. 
11. "Disruptive Desire: Artifice and Indeterminacy in Jacobean Comedy," in Zimmerman, p. 55.

12. Smith, p. 142.

13. Ibid., p. 143.

14. Jo E. Miller, “'And All This Passion for a Boy?': Cross-Dressing and the Sexual Economy of Beaumont and Fletcher's Philaster," English Literary Renaissance, 27 (1997), pp, 129-130.

15. Ibid., p. 131.

16. Finkelpearl, p. 148; Gurr, p. 1; Waith, p. 16; Gordon McMullan, The Politics of Unease in the Plays of John Fletcher (Amherst, MA: University of Massachusetts Press, 1994), esp. pp. 110-115. Jonathan Goldberg, "Fatherly Authority: The Politics of Stuart Family Images" in Rewriting the Renaissance, eds. Margaret W. Ferguson, Maureen Quilligan and Nancy J. Vickers (Chicago: University of Chicago Press, 1986), 3-32, is the first to explore this mutual coding in Fletcher's plays: see Marie H. Loughlin, Hymeneutics: Interpreting Virginity in the Early Modern Stage (Lewisburg, PA: Bucknell University Press, 1997), esp. pp. 48-51, 72-103; and "'Love's Friend and Stranger to Virginitie': The Politics of the Virginal Body in Ben Jonson's Hymenaei and Thomas Campion's The Lord Hay's Masque," English Literary History, 63 (1997), 833-849.

17. Early modern anatomy texts suggest that the unbroken hymen as the unequivocal sign of a woman's physical and spiritual integrity is actually an object of anxious scrutiny and intense debate, with the stability of those material practices dependent on its verifiability (marriage, inheritance, patrilinearity) also called into question. For the full development of this argument, see Loughlin, Hymeneutics, pp. 25-52.

18. For other discussions of Renaissance epistemologies and their relationship to conceptions of subjectivity, see Luke Wilson, "William Harvey's Prelectiones: The Performance of the Body in the Renaissance Theatre of Anatomy," Representations, 17 (1987), 62-95; and Katharine Eisaman Maus, Inwardness and the Drama in Early Modern England (Chicago: University of Chicago Press, 1995).

19. Still Harping on Daughters: Women and the Drama in the Age of Shakespeare (Brighton: Harvester, 1983), pp. 17-18.

20. Waith, pp. 34, 38; and Finkelpearl, p. 153.

21. Ian Fletcher, Beaumont and Fletcher (London: Longmans, Green and Co., 1967), p. 30; and Lee Bliss, Francis Beaumont (Boston: G. K. Hall, 1987), p. 85.

22. Peter H. Davison, "The Serious Concerns of Philaster," English Literary History, 30 (1963), 1-15; and M. G. M. Adkins, "The Citizens in Philaster. Their Function and Significance," Studies in Philology, 43 (1946), 203-212.

23. On the play's "anti-Spanish sentiment," see McMullan, pp. 112-113; "The Second Voyage to Guinea. .." in Richard Hakluyt, The Principal Navigations Voyages and Discoveries of the English Nation (London: George Bishop and Ralph Newberry, 1589), p. 96. 
24. On the relationship between elaborate dress and effeminacy, see Levine, esp. ch. 1; Jardine, pp. 141-168; and Karen Newman, Fashioning Femininity and English Renaissance Drama (Chicago: University of Chicago Press, 1991), pp. 111-127.

25. Miller, p. 141.

26. For a full description of the symptoms of love melancholy, see Jacques Ferrand's encyclopaedic $A$ Treatise on Lovesickness, trans., ed., and with a critical introduction and notes by Donald A. Beecher and Massimo Ciavolella (Syracuse, NY: Syracuse University Press, 1990), esp. pp. 228-231 and 242-255.

27. On the relationship between virginal desire and Protestant marriage, see Loughlin; Hilda Smith, "Gynaecology and Ideology in Seventeenth-Century England," in Liberating Women's History, ed. B. A. Carroll (Urbana: University of Illinois Press, 1976), 97-114; Ian Maclean, The Renaissance Notion of Woman (Cambridge: Cambridge University Press, 1980), esp. pp. 55-88.

28. See Johannes Lange, "Epistola XXI: De Morbo Virgineo," in Classic Descriptions of Disease, ed. Ralph H. Major (Springfield, IL: Charles Thomas, 1932), pp. 488-489; Robert Boyle, "Some considerations touching the usefulnesse of natural philosophy," in Three Hundred Years of Psychiatry, 1535-1860, eds. Richard Hunter and Ida Macalpine (London: Oxford University Press, 1963), p. 132; Lazarus Riverius, The Practice of Physick, comp. and trans. Nicholas Culpeper et al. (London: George Streator, 1668), pp. $83,417,400-403$ and 420-431.

29. Fletcher, p. 27.

30. “'The Gaping Wounds' in the Text of Philaster," Philological Quarterly, 28 (1949), p. 455.

31. On perpetual virginity in post-Reformation England, see Loughlin; Maclean, pp. 57, 85. 